\title{
Lume e a pesquisa do corpo
}

\section{Suzi Frankl Sperber}

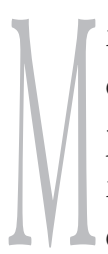

muito já se escreveu sobre a pesquisa de corpo de ator, criada e realizada pelo grupo Lume. Há dois livros publicados e mais três a saírem proximamente. Foram escritos pelos próprios pesquisadores do grupo. O primeiro livro, de Luís Otávio Burnier, o pai da idéia, o encaminhador da pesquisa, o motor e construtor do Lume: o lume do Lume, diria eu. Os outros foram escritos pelos seus discípulos, aproveitando a sua força, criatividade e experiência pessoal. $\mathrm{O}$ que quer dizer que nenhum dos pesquisadores se limitou a apenas imitar o mestre. Cada um, a partir de um empurrão, soube descobrir as suas veredas, sem falsear o aprendizado - levando-o para um aproveitamento mais completo do potencial e das características de cada um. Desta maneira, para além de seguirem uma metodologia e técnica, foram além, redescobrindo-as à maneira de cada um (Renato Ferracini, Ana Cristina Colla, Raquel Scotti Hirson), a partir do ponto em que haviam chegado com o mestre, e seguindo, cada um, rumos novos, em certa medida divergentes e, ao mesmo tempo, complementares. Foi a conquista da liberdade plena, feita de repertório básico, crescente, novas buscas e conquistas, sempre com lucidez, capacidade reflexiva e in- dependência. Os demais atores-pesquisadores do Lume (Carlos Roberto Simioni, Jesser Sebastião de Souza, Naomi Silman e Ricardo Puccetti) também divulgaram suas reflexões, em textos menos longos, mas não menos importantes. E prosseguem: na pesquisa própria de corpo, metodológica, técnica, assim como no apoio coletivo e à coletividade de atores que os procuram. Porque uma das formas de independência foi conseguida a partir da doação. A generosidade, já exercida por Luís Otávio Burnier, foi exercitada por seus companheiros ao longo dos anos. Dar cursos, dar assessoria obriga a verbalizar e a saber mostrar o aprendido, o in-corporado. Num ato de troca - não há doação plena sem recepção. O olhar que percebe a nuança de desvio, de incompletude a ser corrigida ou acertada, aprende a partir do corpo do outro e leva a uma consciência mais clara do que há em si e precisa ser atingido: a organicidade.

Sim, sobre tudo isso já foi escrito. Em que medida o olhar da que se tornou coordenadora por acaso e coordenadora por amor e aposta pode contribuir para iluminar este trabalho, já amplamente conhecido e enaltecido em nível internacional - e valorizado localmente por todos aqueles que com ele tiveram contato? É um

Suzi Frankl Sperber é coordenadora associada do Núcleo Interdisciplinar de Pesquisas Teatrais - Lume e professora de Teoria Literária do Instituto de Estudos da Linguagem da Unicamp. 
outro olhar, de fora, de receptora e de docente, talvez. Ou de ser humano que não perdeu a centelha de vida chamada amor, espargida por aí, desintegrando-se e integrando-se com os que possam aproveitá-la, ou transformá-la em ouro? -, como o são capazes os criadores e dependendo estritamente destes últimos. A centelha em verdade é de chumbo. O criador a apanha e transmuda num projeto alquímico.

Falarei das perplexidades de quem está fora da pesquisa de corpo, cujo corpo vai só sendo marcado por dores, alegrias e a mais funda aposta na energia - nas energias - que emanam de algo paralelo, complementar da organicidade do ator: vida; vida apesar de tudo, mesmo nas experiências limítrofes; vida apesar dos perigos; vida porque doar é do-ar; é doer; é dourar; porque é criação de um espaço de encontro, de encontros, não programados nem voluntários - mas possíveis, sempre abertos, disponíveis. O lugar "entre" não é vazio, como se pode chegar a imaginar. É espaço cheio de partículas de força, de dádiva, de energia vital, capazes de infundir sentido ao encontro, que passa, energizado, a desenvolver-se em outras ricas direçôes, insuspeitas, desconhecidas, formidáveis. $\mathrm{O}$ encontro atribui sentido, até para o que aparentemente não o tem. Ou o que se está gestando, mas ainda não tem nome. Cada pessoa do público - dos espetáculos, das entrevistas, dos workshops, dos encontros - acha-se já com um corpo escrito por alegrias e dores e tantas vezes carente de sentido. $\mathrm{O}$ encontro, porque valoriza o outro, se torna significativo e permite uma troca importante de energias e sentidos.

O trabalho técnico do ator do Lume, este chamado de pré-expressivo, impõe ao corpo do ator que ele chegue à exaustão. $\mathrm{O}$ corpo de pessoa como eu, que não sabe de pré-expressividade, nem de organicidade, se não se negar a chegar aos limites da doação, do sofrimento, da alegria, do cansaço, entrega mais usual dos simples, que não se economizam, imprime neste outro corpo energias e marcas. "Viver é obrigação sempre imediata" (João Guimarães Rosa, "Lá, nas campinas", p. 130). As marcas no corpo da pessoa revelam acolhimento ou defesa dos acontecimentos da existência, nuançam as formas de aproximação, inclinam o tronco, a cabeça, torcem-nos, como árvores ao vento forte, cujo tronco também vai sendo marcado pela passagem do ar - doar. Ora, como conhecer estas torções, o encarquilhamento do corpo e da pele do rosto e das mãos que não se negaram a abraçar as marcas do tempo? $\mathrm{O}$ trauma não marca apenas a enunciação: greta peles, rostos e mãos; leva ao tremor de diferentes partes do corpo e marca a voz. A voz: "lá". ${ }^{1}$ A vibração especial, o lugar do corpo de onde emana, lugar para o qual a voz foi empurrada, recalcada. Como en-cená-la sem fazer o corpo do ator - e sua voz - passarem pelos limites provocados pela exaustão do viver? Como exprimir, apesar de circunstâncias impeditivas, sem levar corpo e voz a aprenderem a vencer circunstâncias paralelas (divergentes?) ao choque, ao trauma, à dor e ao contrário disto: a alegria sem motivo?

Outra questão é saber se a re-apresentação daquilo que foi in-corporado submetendose a esforços paralelos, em que músculos e nervos, voz e tensão foram exigidos, se eles poderão apreender o outro - grande mistério e segredo de revelação. Porque se o duplo é, como o define Vernant, uma "figuração do invisível", o ator é o duplo de invisíveis, diversos, compostos, não um só. E se para Rimbaud "Je est un autre", o eu do ator apreende este, ou estes outros, plurais, somados, que resultam num outro que não será o mesmo, nem o próprio, mas o invisível, que está no ponto de interseção das emanações,

1 Então, ao narrador foge o fio. Toda a história pode resumir-se nisto: - Era uma vez, e nessa vez um homem. Súbito, sem sofrer, diz, afirma: - "Lá..." Mas não acho as palavras (Tutaméia. Rio de Janeiro: Nova Fronteira, 2001, p. 130). 
energias, que se cruzam - e fugazmente, virtualmente se encontram. Só neste procedimento complexo, aparentemente não econômico, pode residir a atribuição de sentido ao ínfimo, ao vil, ao ferido, ao traumatizado. Porque o trauma apequena: os vencedores assumem uma compostura e postura em que a vitória está no corpo banhado em elevada auto-estima. Tornase o corpo visível, que participa de um modelo psicossocial de efeito valorizado. Estes se reúnem. Os outros corpos, feridos, lesionados, aparentemente menos belos, se encolhem na tristeza e solidão, ou diretamente são levados ao isolamento. Encontram-se com os semelhantes, procissão de aleijados, de feridos, marcados pelo sinal de menos, imposto socialmente - e explorado politicamente. No entanto, ali, nas margens - das famílias, das cidades, dos rios, dos lugares -, avultam estes corpos tão expressivos, porque não usam máscaras, não camuflam emoções. Gritam no silêncio as suas experiências. Estes corpos trazem mais matéria expressiva. E exprimi-los pelo corpo do ator lhes dá a visibilidade que lhes é negada socialmente. Porque se o escritor dá voz aos oprimidos - e esta função é importante - os atores podem dar visibilidade aos corpos, esta que também é negada e que precisa ser re-interpretada, re-significada.

O teatro, desde a Antigüidade, retoma estes seres da dor incluindo-os nas tragédias. $\mathrm{O}$ teatro se empenha desde sempre em compreender o sentido da existência - sem sentido para tantos, absurda para tantos - ou para todos os que não se apegam ao sucesso, a "vencer na vida" - e, sem dúvida, só enquanto estão "vencendo na vida”. Revela também as quedas daqueles que uma vez foram belos, saudáveis e poderosos. Não é diferente, neste sentido, o projeto de exercícios pré-expressivos do Lume, sua metodologia, a fim de chegar a um resultado que permita algo diferente da busca de uma objetivação da desgraça, ou no limite da sua impossível explicação. Técnica e metodologia estão a serviço da atribuição de sentido ao fugaz instante do encontro verdadeiro. $\mathrm{O}$ encontro - mesmo que difícil neste nível - é mais facilmente factível e pleno entre os excluídos, os pobres de tudo, que o mais das vezes não usam máscaras, ou o sofrimento que petrificou suas expressões numa máscara de dor revela, por trás da crispação, energias e vida nas lágrimas contidas. Este encontro, existindo, atribui sentido ao outro, que passa a ser pessoa, para além da dor e alegria, em sua pluralidade e diversidade.

Oliver Sacks (1995) considera que a experiência molda o cérebro - e o faz ininterruptamente. Diz que o cérebro é flexível e estruturalmente dependente de suas relações com o mundo, com o outro, com a cultura em que se insere o indivíduo. E com aquilo que é infligido ao corpo e que ele, cérebro, afere, sente, reacomoda, significa ou recalca. Denise Sant'Anna diz: "Cada corpo seria, assim, um vasto território de marcas históricas, um registro mutante e ativo do mundo vivido (incluindo os mundos sonhados, imaginados e lembrados), talvez o mais belo traço que exprime a memória da vida feita de investimentos de poder e de processos de subjetivação. [...] É nele (no corpo) que se expressam, como o brilho de um vaga-lume, a provisoriedade e a finitude de cada ser humano" (Denise Sant'Anna, 2000, p. 84).

Acrescento aquilo que costuma ser esquecido, por razões que desconheço: o cérebro, antes de ser afetado pelo mundo e pelo outro, é, foi afetado pelos genes, por células, por emoções intra-uterinas, de tal forma a poder responder - cada pessoa com o seu cérebro - de maneira diferente, particular e genuína ao mundo, cultura, outro que atua semelhantemente com outras pessoas-cérebros. Esta característica da pessoa esclarece, também, porque o encontro é diferido e ao mesmo tempo almejado. Porque a atribuição de sentido primeira é a um em-si que, significado, já não é, para ser a sua expressão, insuficiente, por isto repetida com variações, repetida e novamente diferida, geradora de novos sentidos, aparentemente imobilizadora, ao mesmo tempo criativa. $\mathrm{O}$ vivido é preenchido de significado, que marca o corpo. O corpo é a superfície em que se inscreve o vivido. Ao tentar significá-lo, ele já não é próprio, porque não 
é mais presente. Inscrito no passado, já não é meu corpo - ao mesmo tempo que o é: aporia fundadora das buscas de significação, sempre diferidas e virtuais. O que foi, já é outro. Este corpo já é o do outro, aquele que será re-significado e, para tanto, apreendido em um espaço virtual, fundamental: o da tentativa de encontro. Não foi à toa que Proust investiu na busca do sentido do tempo perdido, chegando a formular a existência como somatória em linhas aparentemente paralelas, porém, em espiral. O corpo próprio e o alheio são marcados pela somatória de acontecimentos, que não se anulam mutuamente, nem se sobrepóem. $\mathrm{O}$ sentido momentâneo juntará aspectos do vivido, que variarão conforme os estímulos, as palavras, imagens, sensaçôes, sentidos percebidos num encontro - que se dá, sem deixar de ser virtual e que nunca é o mesmo, nem completo.

Para o ator importa o gesto de sair de si e deixar seu próprio corpo de ator ser escrito pela tentativa de acolhimento, pelo reconhecimento de que Narciso é belo e perece, mas quem reflete são as águas cristalinas. $\mathrm{O}$ ator precisa mergulhar nestas águas, desarranjá-las de seu imobilismo, a fim de ver além da própria face. Para que isto ocorra, não basta, ao ator, um treinamento atlético, que lhe possibilite um perfeito controle sobre seu corpo. Diz José Amâncio Tonezzi Rodrigues Pereira ${ }^{2}$ que: "É preciso torná-lo capaz de inserir-se num sistema metafórico, transformá-lo num provocador da imaginação. O seu corpo deve tornar-se teatralmente 'falante' e 'presente'". Parece simples. De que maneira um corpo se "insere num sistema metafórico"? Segundo José Pereira (2003): "A cena [...] detém certos aspectos que vão além do puro virtuosismo presente nos experimentos técnicos e científicos e (que) constituem, de certa maneira, uma resistência a eles. Um tanto alheio aos avanços no campo científico, o corpo cênico congrega características específicas que brin- dam o imprevisto, o improviso e a sensibilidade como seus componentes diferenciadores". Sim. E não. Como se dá a passagem da presença, para a presença com sentido? Quem atribui sentido? O ator ou o receptor? Como se dá o salto de significação?

Em seus primórdios, centrada sobre a fala, a cena teatral relegava ao corpo uma função quase alegórica, reforçada pelos códigos estabelecidos para com os demais componentes da cena. Obviamente, o corpo tinha a sua importância, mas a sua presença era ampliada mais do que por seus próprios recursos, por implementos externos. Ao que parece, na Grécia Antiga, a codificação era feita a partir das cores das túnicas que determinavam a categoria social dos personagens. Coturnos eram utilizados a fim de aumentar a estatura dos atores e máscaras ampliavam a expressão do rosto, criando um certo estranhamento. Nesse caso, um dos motivos concretos era a dimensão do espaço e a distância que separava o ator do espectador.

$\mathrm{O}$ poder do disfarce, assim como o dom da metamorfose do espaço, são componentes essenciais à arte da cena. Intervêm como instrumento de deformação ou de transformação do físico do ator, assim como o figurino e outros elementos de caracterização. Nesse sentido, (e só nesse sentido) são parte integrante do corpo do ator. Mas são máscaras. Conforme Peter Brook (1988), há duas categorias de máscaras: a horrível e a boa. A primeira seria mais freqüentemente utilizada no teatro ocidental. Seria a máscara confeccionada por um decorador, que trabalha a partir de seu imaginário. Diante da prancheta, desenha uma soma de formas - que se não forem preenchidas a partir de dentro serão enganosas e deformadoras. Em cena, o produto de seu trabalho é colocado sobre outra máscara, a face do ator, que talvez mal conhece o significado deste ato. Ocorrendo isto, o público terá a impressão de estar diante de algo

2 Pereira, 2003, p. 60. 
engessado e pertencente a um domínio oculto - eventualmente ocupado com traumas e frustraçōes pessoais.

A máscara tradicional - oriental - operaria de outra maneira, não sendo exatamente uma máscara, mas uma imagem essencial da natureza:

"Em outros termos, a máscara tradicional é o retrato de um homem sem máscara, um retrato da alma, uma fotografia do que raramente se vê, e somente nos seres humanos evoluídos" (Brook, 1988, p. 193).

Para Peter Brook o produto artístico não seria imitação, mas expressão - da natureza segundo preceitos zen-budistas.

Os atores do Lume trabalham com o que foi chamado de mímesis corpórea. Deveria ela ser entendida exatamente como a idéia ocidental de arte, isto é, a arte como imitação das coisas e da natureza? Diz-se que, na obra do artista, o poder da própria paixão é convertido em força criadora, experimentando-se, então, o processo dinâmico da vida - a contínua oscilação entre sentimento e sensações opostas (alegria e tristeza, esperança e medo, exultação e desespero). A mímesis corpórea do Lume não deve ser entendida como idêntica à idéia de mímesis acima exposta. Ela é somada aos exercícios pré-expressivos - treinamento cotidiano do ator - ao cômico (clown) e à dança pessoal. A exaustão do treinamento não apenas prepara o corpo forte, resistente. Antes de tudo, esvazia corpo e mente de referências e sentidos. Como diz Guimarães Rosa, no conto "S. Marcos", 3 é preciso que o material especial de trabalho do artista (no caso do ficcionista, a palavra; no caso do ator, o corpo e a voz) volte a ser selvagem, isto é, se esvazie de sentidos. Só então este material poderá preencher-se de energias que poderão ser investidas, no encontro com o receptor, de outras energias, às quais o receptor atribuirá sentidos. Não são metáforas. São energias, vibraçôes, movimentos, expressões, vivos, intensos, que detonam e ecoam. As palavras, a cena, as luzes, o som, a música, os acessórios, todos compóem um quadro que orienta o rumo das significações que os receptores atribuirão à cena. Portanto, o sentido não será tão aleatório, nem tão errante. Por isto é possível haver encontros nos encontros, de percepção, de sensações e mesmo de sentidos. E o encontro só é possível porque a energia liberada pelo corpo e a voz dos atores se dá para um outro e para outros, porque soube e souberam recebê-los simetricamente, sem desqualificações - e sem qualificaçōes. É uma entrega plena e gratuita, no seu sentido original - de graça, pela e na graça. Que encontrará pessoas sedentas de encontros verdadeiros, de graça e na graça. O belo da cena, constituído pelo conjunto que abrange e parte do corpo e da voz dos atores, elemento estético sem o qual não há arte, faculta o salto de qualidade e de sentido. Estes momentos têm algo de mágico e grandioso - comoventes sem serem lacrimogêneos. Incluem, claro, juntamente com tudo o que compóe a cena, a arte do ator - doador - dor-a-dor - doação, ação, que, de repente, reluz na alegria do encontro.

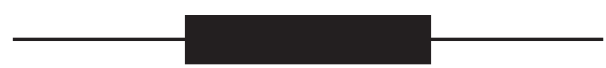

3 'E que o menino Francisquinho levou susto e chorou, um dia, com medo da toada 'patranha' - que ele repetira, alto, quinze ou doze vezes por brincadeira boba, e, pois, se desusara por esse uso e voltara a ser selvagem" (Rosa, 1964, p. 236). 


\section{Referências bibliográficas}

BROOK, Peter. "Mensonge et superbe adjectif”, in Le masque - Du rite au théâtre. Paris: Editions du CNRS, 1988.

BURNIER, Luís Otávio. Arte de ator - Da técnica à representação. Campinas: Editora da Unicamp e FAPESP, 2002.

COLLA, Ana Cristina. "Da minha janela vejo... relato de uma pesquisa pessoal de pesquisa no Lume”. Dissertação de Mestrado. Campinas: Universidade Estadual de Campinas, 2003.

FERRACINI, Renato. A arte de não interpretar como poesia corpórea do ator. Campinas: Editora da Unicamp, IMPRENSA OFICIAL e FAPESP, 2002.

FERRACINI, Renato. "Mímesis corpórea - a teatralização do cotidiano". Tese de doutorado. Campinas: Universidade Estadual de Campinas, 2002

HIRSON, Raquel Scotti. “Tal qual apanhei do pé”. Dissertação de Mestrado. Campinas: Universidade Estadual de Campinas, 2003.

PEREIRA, José Amâncio Tonezzi Rodrigues. "A arte do ator e o ato do afásico". Dissertação de Mestrado. Faculdade de Educação. Campinas: Unicamp, 2003. Acesso em: <http://libdigi. unicamp.br/document/?code=vtls000297412>.

Revista do LUME. Número 01, 1998.

Revista do LUME. Número 02, 1999.

Revista do LUME. Número 03. 2000.

Revista do LUME. Número 04. 2001.

Revista do LUME. Número 05. 2003. Edição especial.

Revista do LUME. Número 06. 2005.

ROSA, João Guimarães. “S. Marcos”. In: Sagarana. Rio de Janeiro: José Olympio, 1964. . “Lá, nas campinas”. In: Tutaméia. Rio de Janeiro: Nova Fronteira, 2001.

SACKS, O. Um antropólogo em Marte. São Paulo: Companhia das Letras, 1995.

SANT'ANNA, D. B. (org.). Corpo, ética e cultura. In: BRUHNS, H. T. \& GUTIERREZ, G. L. (org.). O corpo e o lúdico. Campinas: Editores Associados, 2000. 